УДК 351.82: 330.341.1

https://doi.org/10.34142/24130060.2020.21.2.09

\title{
МЕХАНІЗМИ РЕАЛІЗАЦІЇ ДЕРЖАВНОЇ ІННОВАЦІЙНОЇ ПОЛІТИКИ У КОНТЕКСТІ ПОДОЛАННЯ ЕКОНОМІЧНОЇ ТА СОЦІАЛЬНОЇ КРИЗИ 2020
}

\author{
І. П. Шепеленко, О. Г. Шепеленко \\ Харківський національний педагогічний університет імені Г.С. Сковороди
}

За умов необхідності подолання економічної та сочіальної кризи 2020, наслідків коронавірусної хвороби (COVID-19) зростає роль державного управління щзодо пошуку механізмів, спрямованих на розвиток та підтримку інноваційного бізнесу, інноваційних сочіальних проектів. Сучасні інновачійні розробки повинні бути переформатовані та спрямовані державою на розвиток перспективних галузей, необхідна також система фінансування та підтримки інноваційних проектів різного рівня. Формування особливих економічних, фінансових, організачійних і нормативно-правових умов дозволяє державі, як ніякому іншому сочіальному інститутові, стимулювати активність в інноваційній сфері Украӥни, щчо, в свою чергу, дає можливість для ефективного виходу краӥни з кризи 2020.

Ключові слова: державне управління, інновачії, економічна криза

\section{МЕХАНИЗМЫ РЕАЛИЗАЦИИ ГОСУДАРСТВЕННОЙ ИННОВАЦИОННОЙ ПОЛИТИКИ В КОНТЕКСТЕ ПРЕОДОЛЕНИЯ ЭКОНОМИЧЕСКОГО И СОЦИАЛЬНОГО КРИЗИСА 2020}

\section{И. П. Шепеленко, Е. Г. Шепеленко}

\begin{abstract}
В условиях необходимости преодоления экономического и сочиального кризиса 2020, последствий коронавирусной болезни (COVID-19) возрастает роль государственного управления по поиску механизмов, направленных на развитие и поддержку инновационного бизнеса, инновационных соичильных проектов. Современные инновачионные разработки должны быть переформатировань и направлень государством на развитие перспективных отраслей, необходима также система финансирования и поддержки инновационных проектов разного уровня. Формирование особых экономических, финансовых, организационных и нормативно-правовых условий позволяет государству, как ни одному другому сочиальному институту, стимулировать активность в инновационной сфере Украины, что, в свою очередь, дает возможность для эффективного выхода страны из кризиса 2020.
\end{abstract}

Ключевые слова: государственное управление, инновации, экономический кризис

(C) І. П. Шепеленко, О. Г. Шепеленко, 2020 


\section{MECHANISMS FOR IMPLEMENTING STATE INNOVATIVE POLICIES IN CONTEXT OF OVERCOMING THE ECONOMIC AND SOCIAL CRISIS 2020}

\section{Shepelenko, O. Shepelenko}

Keywords In the context of the need to overcome the economic and social crisis of 2020, the consequences of the coronavirus disease (COVID-19), the role of the state administration in finding mechanisms aimed at developing and supporting innovative business and innovative social projects is increasing. Modern innovative developments should be reformatted and directed by the state towards the development of promising industries. A system of financing and support of innovative projects of different levels is also needed. The formation of special economic, financial, organizational and regulatory conditions allows the state, like no other social institution, to stimulate activity in the innovation sphere of Ukraine, which, in turn, makes it possible for the country to effectively exit the 2020 crisis.

The main problem is the low rate of implementation of innovative developments, which in recent years has decreased to a critical level, which has become a threat to national security. Regional programs and specialized centers focused on the competitiveness of the Ukrainian economy have not received sufficient support from the state in recent years. However, it is the state that should integrate the best achievements of general scientific and sectoral methodology into practice; play a decisive role in setting priorities, strategies and mechanisms for ensuring the development of the economy of the country on an innovative basis.

The study of the successful experience of industrialized countries made it possible to determine a number of practical principles of stimulating innovation, increasing the competitiveness of regions by the following means: orientation of the state innovation policy towards the demonstration effect of the implemented projects, and not on direct macroeconomic results; stimulation of new types of activity in all industries and sectors of the economy; decentralization of state support and formation of a network of «development institutions», cofinancing of projects (attraction of budgetary funds); systematic monitoring of the state of innovative components at the regional level, external assessment and benchmarking; providing innovators with services instead of money; communication among main players: government, science and business as a condition for building trust in government; personal reputation of managers as a factor in building trust in new institutions for promoting innovative products, projects, and inventions at the regional level.

Key words: public administration, innovation, economic crisis

Постановка проблеми. На момент написання цієї статті світ щосили намагається впоратися 3 економічними i соціальними наслідками коронавірусної хвороби (COVID-19). Внаслідок пандемї коронавірусу та введених карантинних заходів падіння українського ВВП за даними Міністерства розвитку економіки, торгівлі та сільського господарства першій половині 2020 р. склало 6,5\% (Ukrains’ka pravda, 2020b).

У той же час за оцінкою МВФ, українська економіка зменшиться за підсумками 2020 року на 8,2\% (Liha. Novosty, 2020 ). 
Внаслідок введення карантину українські компанії заморозили інвестиції, інноваційні проекти та існуючі виробничі ланцюжки. Найбільші втрати понесли галузі роздрібної торгівлі, туристичного, готельного та ресторанного бізнесу, транспортної галузі, зокрема авіаперевезень. Після першої хвилі карантинних заходів роздрібна торгівля та сфера послуг здійснили спробу відновитись, але на початку нового року їх знов чекають суттєві випробування. Дуже складною ситуація склалася в галузях машинобудування, паливної та металургійної, хімічної та нафтохімічної промисловості, сфери торгівлі, вантажних та пасажирських перевезень, де підприємства пережили найсильніший спад. Але найгіршим $є$ те, що карантин обрушив споживчі настрої населення. Рівень безробіття за оцінками Торгово-промислової палати України становить 13,7-15,4\%. Це найвищий показник за останній 15 років (Ukrains’ka pravda, 2020a). Третина українців повністю втратила дохід або роботу, а регулярний дохід родини зменшився вдвічі. I прогноз щодо поліпшення та зростання реальної заробітної плати за оцінками НБУ найближчим часом не очікується (Natsional'nyj bank Ukrainy, 2020). Пандемія коронавірусу виявилась складним випробуванням і для української системи освіти та науки. Таким чином, можна констатувати, що Україна увійшла в поточну економічну кризу з почасти збалансованою макроекономічною ситуацією. Маловтішними $\epsilon$ альтернативні прогнози щодо рівня кризового падіння економіки України:

- $\quad$ Уряд прогнозує, що у 2020 році економіка України впаде на 4,8\%.

- $\quad$ МВФ дає набагато песимістичний прогноз - 8,2\% падіння ВВП.

- $\quad$ Експерти в консенсус-прогнозі від Мінекономіки вважають, що економіка впаде на 6\% (24 kanal, 2020).

За таких умов зростає роль механізмів державного управління у пошуку інноваційних підходів та шляхів виходу з кризи, сталого зростання та підвищення конкурентоспроможності національної економіки. Сучасні інноваційні розробки повинні бути переформатовані та спрямовані державою на розвиток перспективних галузей. 
Аналіз актуальних досліджень. Теоретичне розроблення проблем державної політики, спрямованої на підтримку інноваційних підприємств, започатковано зарубіжними науковцями Л. Ерхардом, К. Лампертом, К. Мікульським, Б. Санто, Й. Шумпетером.

Так, Й. Шумпетер розглядав інновацію як засіб подолання економічних криз. На основі теорії «довгих» кон’юнктурних хвиль ділової активності він виявив нову можливість виведення виробничої системи з кризи, пов’язану ні 3 ростом масштабів діяльності, скороченням витрат або зростанням ціни на колишню продукцію, а зі зміною в господарському процесі за рахунок створення і впровадження інновацій. До інновацій він відносив:

1) виготовлення нового продукту;

2) впровадження нового методу виробництва;

3) освоєння нового ринку збуту;

4) отримання нового джерела сировини;

5) проведення реорганізації (галузі) (Shumpeter, 1982).

На думку послідовника Й. Шумпетера - М. Калецького - інновації стимулюють економічний розвиток, забезпечують в довгостроковій перспективі скорочення тривалості економічних спадів і подовжують періоди підйомів. Санто Б. (1990) наголошував на необхідності поширення інноваційного мислення представників всіх щаблів управління економікою. Л. Ерхард — міністр економіки в уряді Конрада Аденауера (1949-1963) і його наступник на посту федерального канцлера ФРН - на практиці довів, що, незважаючи на страшні труднощі 1948-1949 pp. та жорсткий опір опонентів, зусилля держави, спрямовані на лібералізацію економіки та підтримку інноваційних підприємств, стають основою стабільної економіки та розвинутої країни.

В Україні дослідженню засад державного регулювання інноваційної діяльності присвячені праці О. Алімова, В. Бакуменка, Л. Безчасного, С. Газарян, М. Гамана, Б. Данилишина, О. Дація, А. Дєгтяра, М. Корецького, С. Майстра, С. Попова, М. Федулової, Ю. Ульянченка та ін. Сучасний 
інструментарій державної політики стимулювання інноваційно-інвестиційної діяльності визначили Я. Базилюк, Я. Жаліло. Інноваційні моделі державного регулювання економіки досліджували О. Амоша, С. Біла, I. Бистряков, М. Бутко, А. Гальчинський, В. Геєць, В. Гусєв, А. Лісецький, В. Мельник, В. Чіжов, А. Чухно, М. Якубовський. Механізми комунікативної взаємодії органів влади та соціальних інститутів в системі інноваційної політики аналізували Кіктенко О.В., Ю. Бажал, Л. Мусіна, Б. Гриньов, П. Губенко, В. Гусєв та ін.

Таким чином, науковцями досить повно представлені теоретичнометодологічні засади дослідження механізмів реалізації державної інноваційної політики.

Мета статті полягає в обгрунтуванні механізмів реалізації державної інноваційної політики для подолання економічної та соціальної кризи 2020.

Виклад основного матеріалу. В Україні накопичений величезний науково-інноваційний потенціал, який міг би стати основою для подолання економічної кризи 2020. Не дивлячись на те, що з 1990 року чисельність науковців України скоротилася більш, ніж в 4 рази, і продовжує зменшуватися, а державне фінансування науки є невеликим - 6,1 млрд гривень (2018 р.). При цьому більше половини державних коштів на науку отримує Національна академія наук України, а регіональні наукові центри та університети залишилися на самозабезпеченні (Korrespondent.net., 2018).

Але основною проблемою є низький показник втілення інноваційних розробок, який за останні роки знизився до критичного рівня, що стало загрозою національній безпеці. Регіональні програми, спеціалізовані центри, орієнтовані на конкурентоспроможність української економіки, за останні роки не отримали достатньої підтримки з боку держави. Проте саме держава має інтегрувати кращі досягнення загальнонаукової і галузевої методології у практику; грати вирішальну роль у визначенні пріоритетів, стратегії та механізмів забезпечення розвитку економіки країни на інноваційній основі. 
Інноваційна політика є найважливішою частиною загальної соціальноекономічної політики держави, в якій зафіксовані ключові найважливіші цілі, напрями та методи взаємодії органів державної влади на шляху досягнення результатів у сфері науки і техніки.

Необхідність участі держави в інноваційному процесі на всіх його етапах обумовлена тим, що держава $\epsilon$ ключовим учасником процесу формування довгострокової стратегії розвитку країни в цілому, i інноваційному - зокрема; держава визначає стратегію реалізації інновацій в неринковому секторі економіки; держава створює попит на співробітників сфери інновацій; держава визначає потребу в захисті інтелектуальної власності (Shepelenko, 2015).

Формування особливих економічних, фінансових, організаційних і нормативно-правових умов дозволяє державі стимулювати активність в інноваційній сфері. До ключових необхідних механізмів регулювання державою інноваційної діяльності можна віднести: підтримання стабільного зростання пропозиції з боку сфери інновацій; створення робочих місць і попиту на перспективний кадровий резерв в інноваційній сфері; надання пільг підприємствам, що застосовують інноваційні процеси, продукти, послуги; стимулювання модернізації техніки; боротьба з недобросовісною конкуренцією; стимулювання підтримки інноваційних проектів зовнішньоекономічними агентами; розвиток інструментів фінансової підтримки; створення і підтримання сприятливого клімату для вливання інвестицій в інноваційні продукти; формування та реалізація державних, галузевих і регіональних інноваційних програм; створення і підтримання стабільного і рівномірного розвитку інноваційної інфраструктури; інформаційне забезпечення сфери інновацій; організація для новаторів локального доступу до технологічного аналізу і пов'язаним з ними послуг в області інтелектуальної власності, які їм необхідні для повної реалізації та захисту своїх прав IB; допомога в просуванні на світових ринках результатів вітчизняної інноваційної активності; створення наукових центрів, бізнес- 
інкубаторів малого бізнесу, технопарків; охорона прав і захист інтересів суб’єктів інноваційної активності.

Таким чином, держава, виступаючи каталізатором в процесі зародження інноваційних процесів у всіх сферах економіки країни, виконує наступні функції:

- пріоритизація напрямів, стратегій розвитку інноваційної сфери;

- фінансування інноваційної діяльності;

- координація інноваційної діяльності;

- стимулювання інноваційної активності;

- $\quad$ правове регулювання інноваційної діяльності, захист прав на інтелектуальну власність;

- створення кадрового потенціалу;

- $\quad$ формування сприятливого інфраструктури, в тому числі розвиток механізмів підтримки інноваційної діяльності, що включають техніковпроваджувальні особливі економічні зони, які передбачають значні пільги інноваційним компаніям, наукові містечка, технопарки, бізнес-інкубатори, центри трансферу технологій i федеральні центри колективного користування науковим обладнанням (Shepelenko, 2014);

- $\quad$ регулювання міжнародних аспектів інноваційних процесів.

Аналіз механізмів реалізації державної інноваційної політики провідних країн, які вже досягли високого рівня інноваційного розвитку (США, Тайвань, Ізраїль, Фінляндія), дозволив дійти висновку, що регіональні програми соціально-економічного та інноваційного розвитку в розвинених індустріальних країнах почали розроблятися і здійснюватися набагато раніше, ніж загальнодержавні програми. При чому налагодження горизонтальних зв'язків між різними суб'єктами інноваційної діяльності: місцевими органами влади, галузевою та академічною наукою, консалтинговими та впроваджувальними фірмами, малими підприємствами, інвесторами, - призводить до нарощення інноваційного потенціалу регіонів. 
Дослідження успішного досвіду індустріальних країн дозволило визначити низку практичних принципів стимулювання інновацій, підвищення конкурентоспроможності регіонів: орієнтація державної інноваційної політики на демонстраційний ефект від реалізованих проектів, а не на прямі макроекономічні результати; стимулювання нових видів активності в усіх галузях і секторах економіки, а не секторів чи галузей; децентралізація державної підтримки і формування мережі «інститутів розвитку», співфінансування проектів (залучення бюджетних i позабюджетних коштів); систематичне проведення моніторингу стану інноваційних складових на рівні регіону, зовнішнього оцінювання та бенчмаркінгу; надання інноваторам послуг замість грошових коштів; комунікація між урядом, наукою та бізнесом як умова формування довіри до влади; особиста репутація керуючих як чинник формування довіри до нових інститутів просування інноваційної продукції, проектів, ноу-хау на регіональному рівні.

Так, наприклад, в умовах економічного спаду i боротьби 3 короновірусом уряд Індії пропонує різні податкові пільги для інноваторів та винахідників в будь-якій сфері діяльності. Департамент наукових i промислових досліджень (DSIR) фінансує і направляє інноваційну діяльність, що виконують установи, академічні кола та промисловість для підтримки і розвитку економіки Індії. Рада з розвитку технологій (TDB) при уряді Індії також є важливою зацікавленою стороною в розвитку індійської інноваційної екосистеми, яка надає пільгові кредити і сприяє підвищенню ефективності промисловості, торгівлі і сільського господарства за рахунок комерціалізації місцевих технологій та адаптації імпортних технологій до застосування в регіональних умовах. Рада зі сприяння галузевим дослідженням (BIRAC) підтримує групи високого інноваційного ризику, учасниками яких є молоді вчені з академічних кіл, стартапів або інкубаторів, які презентують цікаві ідеї на стадії зародження або планування. Сьогодні в Індії спостерігається суттєве 
зростання національних та іноземних приватних організацій акціонерного / венчурного капіталу (PE / VC).

Однак уряд також грає важливу роль в становленні і розвитку галузей промисловості різними фіскальними поступками. Фінансові інститути, такі як Банк промислового розвитку Індії (IDBI) i Банк розвитку малих підприємств Індії (SIDBI) крім підприємців підтримують інновації та комерціалізацію інноваційних технологій. SIDBI управляє Індійським інноваційним фондом - зареєстрованим венчурним фондом, що інвестує в інноваційні індійські фірми на ранній стадії формування інновацій. Незважаючи на наявність декількох інструментів, багато геніальних ідей підприємців, особливо тих, що знаходяться на низовому соціальному рівні, не приносять результати через неможливість доступу до відповідних джерел фінансування. Сьогодні уряд Індії вважає абсолютно необхідним, щоб всі потенційні ідеї, навіть з найвіддаленіших куточків світу, повинні мати можливість знайти своє місце і бути використані в індійській економіці, якщо вони відповідають іiї потребам. Урядом Індії за мету обрано в період сучасної світової кризи розробити надійний механізм перевірки інноваційних технологій та продуктів, а також сформувати джерела фінансування, за допомогою яких можуть бути реалізовані 5000 ретельно відібраних, кращих ідей 3 усього світу, які мають перспективу розвиватися від ідеї до комерціалізації і принести користь індійському суспільству. Крім того, експерти відзначають, що в подальшому існує гостра потреба в великомасштабному державному органі, який би виконував функцію гаранта високоризикових інновацій зі значним бізнес-потенціалом.

У постсоціалістичних країнах, що застосовують інноваційні моделі швидкими темпами (Казахстан, Білорусь, Латвія, Туркменія), все більших масштабів в інноваційному процесі набуває участь держави, яка визначає стратегію та тактику регіонального інноваційного розвитку.

У зв'язку зі зростаючою на фоні сучасної кризи увагою до інновацій як до способу створення стійкого та інклюзивного майбутнього, саме зараз 
особливо актуальним для нашої країни є те, хто буде фінансувати інновації, наскільки українська держава готова фінансово та організаційно підтримувати наукові кадри? Поки існують інновації, головне завдання, що стоїть перед новатором у всьому світі, - це мобілізація стабільних і доступних механізмів фінансування, можливості використовувати історично максимально можливі ресурси для наукової діяльності. Фінансування впливає на всі стадії інноваційного циклу, від ідеї до комерціалізації, розширення i, в кінцевому підсумку, довгострокової стійкості окремого бізнесу, цілої сфери економіки, суспільства в цілому.

Ще до кризи ряд нових суб’єктів інноваційної діяльності розвинених країн, такі як суверенні фонди добробуту i некомерційні організації, підтримували інновації, вкладали кошти в розвиток як цілісних інноваційних стратегій, так і в окремі продуктові, процесні, технічні, управлінські та організаційні технології. Фінансування інновацій може також здійснюватися в результаті діяльності корпоративних підприємств, завдяки дії торгових майданчиків інтелектуальної власності, краудфандінга та інших видів сприяння інноваціям, які були до кризи і нікуди не зникнуть. Але в той же час схеми державної підтримки залишаються найважливішими інструментами фінансування та організації інновацій.

Одним 3 наслідків поточної кризи є розвиток інтересу до інноваційних рішень в медицині, фармакології, менеджменті та організації віддаленої роботи та навчання, в електронній комерції та мобільному зв’язку, логістиці та транспорті. Опосередковано, але вельми істотно, поточна криза позитивно вплинула на розкриття проблеми скорочення довгострокової зміни клімату. Так, наприклад, IT-сфера у поточному році в Україні постраждала менше, аніж інші галузі. До пандемії коронавірусу вітчизняний IT-сектор зростав на 2530\% щорічно. В цьому році зростання не припинилося, хоча i не досягло минулорічних показників. Понад 1600 компаній та велика кількість самозайнятих спеціалістів надають IT-послуги в Україні. Станом на травень 2020 року (за даними Мін’юсту) в Україні налічувалось близько 200000 спеціалістів. Таким чином українська IT-індустрія зберегла своє феноменальне зростання у 25-30\% щорічно та є провідною галуззю. 
Таким чином, кожна криза приносить можливості і місце для творчого зрушення. Завдання державних органів влади - не прогавити злети творчої діяльності в суспільстві і організаційно та фінансово підтримати науковців та новаторів на благо розвитку та безпеки країни.

Висновки і перспективи подальших досліджень. Зараз, як ніколи раніше, інновації - це надія людства на подолання економічної ізоляції, подолання кризових явищ у всіх сферах життя. Ця пандемія $є$ потужним нагадуванням, що дослідження і розробки, пов’язані, зокрема, зі здоров'ям, i інновації в системі охорони здоров’я - це не розкіш, а необхідність. У найближчі роки неприйняття ризику буде високим, як країнам, так i корпораціям і підприємствам буде важче добиватися впровадження інвестицій та інновацій. Тому може виникнути спокуса відкласти досягнення більш довгострокових цілей, але досвід подолання попередніх економічних криз показує, що виграє економіка і суспільство в цілому тієї країни, яка орієнтувалася на інноваційний розвиток і де держава підтримувала інноваційні спрямування бізнесу.

\section{ЛІТЕРАТУРА}

1. 24 канал, 2020. Наслідки локдауну 2.0 для економіки Украӥни: що буде з ВВП, бюджетом та бізнесом. [online] (Останне оновлення 1 жовтень 2020) Доступно: https://economy.24tv.ua/naslidki-lokdaunuv-ukrayini-shho-bude-z-vvp-byudzhetomiznesom_n147448 [Дата звернення 15 вересень 2020].

2. Корреспондент.net., 2018. Украина увеличила финансирование науки на треть. [online] (Последнее обновление 4 январь) Доступно: https://korrespondent.net/ukraine/3925312ukrayna-uvelychyla-fynansyrovanye-naukyna-tret [Дата обращения 15 сентябрь 2020].

3. Ліга. Новости, 2020. МВФ погіршив прогноз падіння ВВП України в 2020 рочі. [online] (Останнє оновлення 10 червень 2020) Доступно: https://uanews.liga.net/economics/news/mvfpogirshivprognoz-padinnya-vvp-ukraini-v-2020-rotsi [Дата звернення 15 вересень 2020]

4. Національний банк України, 2020. Макроекономічний та монетарний огляд Національного банку Украӥни. [online] Доступно:

\section{REFERENCES}

1. 24 kanal, 2020. Naslidky lokdaunu 2.0 dlia ekonomiky Ukrainy: scho bude z VVP, biudzhetom ta biznesom. [online] (Ostannie onovlennia 1 zhovten' 2020) Dostupno: https://economy.24tv.ua/naslidki-lokdaunuv-ukrayini-shho-bude-z-vvp-byudzhetomiznesom_n147448 [Data zvernennia 15 veresen’ 2020].

2. Korrespondent.net., 2018. Ukraina uvelichila finansirovanie nauki na tret. [online] (Poslednee obnovlenie 4 yanvar) Dostupno: https://korrespondent.net/ukraine/3925312ukrayna-uvelychyla-fynansyrovanye-naukyna-tret [Data obrascheniya 15 sentyabr 2020].

3. Liha. Novosty, 2020. MVF pohirshyv prohnoz padinnia VVP Ukrainy v 2020 rotsi. [online] (Ostannie onovlennia 10 cherven' 2020) Dostupno: https://uanews.liga.net/economics/news/mvfpogirshivprognoz-padinnya-vvp-ukraini-v-2020-rotsi [Data zvernennia 15 veresen' 2020]

4. Natsional'nyj bank Ukrainy, 2020. Makroekonomichnyj ta monetarnyj ohliad Natsional'noho banku Ukrainy. [online] Dostupno: 
https://bank.gov.ua/admin_uploads/article/M M_2020-06.pdf?v=4 [Дата звернення 15 вересень 2020].

5. Санто, Б., 1990. Инновачия как средство экономического развития. Перевод с венгерского Б. В. Сазонова. Москва: Прогресс.

6. Українська правда, 2020а. Кількість безробітних в Україні за час карантину зросла на 1-1,3 мільйонів людей - ТПП. [online] (Останнє оновлення 16 квітень 2020) Доступно: https://www.epravda.com.ua/news/2020/04/1 6/659462/ [Дата звернення 15 вересень 2020].

7. Українська правда, 2020b. Украӥнська економіка впала за півроку на 6,5\%. У другому кварталі - на $11 \%$. [online] (Останнє оновлення 6 серпень 2020) Доступно:

https://www.epravda.com.ua/news/2020/08/6 /663774/ [Дата звернення 20 серпень 2020].

8. Шепеленко, О. Г., 2014. Роль ЦНАП у формуванні інноваційного клімату в регіоні. В: Засоби забезпечення надання якісних адміністративних послуг на рівні територіальної громади: Матеріали науково-практичної конферениії. Одеса, Україна, 30 червня - 04 липня 2014. Одеса : ОРІДУ НАДУ.

9. Шепеленко, О. Г., 2015. Методологія визначення інноваційної конкурентоспроможності регіонів. Аспекти публічного управління, 10 (24), с. 63-68.

10. Шумпетер, Й., 1982. экономического развития (Исследование предпринимательской прибыли, капитала, кредита, процента и ичикла конъюнктуры). Перевод с английского В. С. Автономов, М. С. Любский, А. Ю. Чепуренко. Москва: Прогресс.

11. Шумпетер, Й., 1995. Капитализм, социализм и демократия. Перевод с английского В.С. Автономова Москва: Экономика.
https://bank.gov.ua/admin_uploads/article/M M_2020-06.pdf?v=4 [Data zvernennia 15 veresen' 2020].

5. Santo, B., 1990. Innovatsiya kak sredstvo ekonomicheskogo razvitiya. Perevod s vengerskogo $\mathrm{B}$. V. Sazonova. Moskva: Progress.

6. Ukrains'ka pravda, 2020a. Kil'kist' bezrobitnykh $v$ Ukraini za chas karantynu zrosla na 1-1,3 mil'joniv liudej - TPP. [online] (Ostannie onovlennia 16 kviten' 2020) Dostupno: https://www.epravda.com.ua/news/2020/04/1 6/659462/ [Data zvernennia 15 veresen' 2020].

7. Ukrains'ka pravda, 2020b. Ukrains'ka ekonomika vpala za pivroku na 6,5\%. U druhomu kvartali - na 11\%. [online] (Ostannie onovlennia 6 serpen’ 2020) Dostupno: https://www.epravda.com.ua/news/2020/08/6 /663774/ [Data zvernennia 20 serpen’ 2020].

8. Shepelenko, O. H., 2014. Rol' TsNAP u formuvanni innovatsijnoho klimatu $\mathrm{v}$ rehioni. V: Zasoby zabezpechennia nadannia iakisnykh administratyvnykh posluh na rivni terytorial'noi hromady: Materialy naukovopraktychnoi konferentsii. Odesa, Ukraina, 30 chervnia - 04 lypnia 2014. Odesa : ORIDU NADU.

9. Shepelenko, O. H., 2015. Metodolohiia vyznachennia innovatsijnoi konkurentospromozhnosti rehioniv. Aspekty publichnoho upravlinnia, 10 (24), s. 63-68.

10. Shumpeter, Y., $1982 . \quad$ Teoriya ekonomicheskogo razvitiya (Issledovanie predprinimatelskoy pribyili, kapitala, kredita, protsenta i tsikla kon'yunkturyi). Perevod s angliyskogo V. S. Avtonomov, M. S. Lyubskiy, A. Yu. Chepurenko. Moskva: Progress.

11. Shumpeter, Y., 1995. Kapitalizm, sotsializm i demokratiya. Perevod s angliyskogo V.S. Avtonomova Moskva: Ekonomika.

\section{Інформація про авторів}

Шепеленко Ірина Павлівна - кандидат соціологічних наук, доцент кафедри політології, соціології і культурології Харківського національного педагогічного університету імені Г. С. Сковороди; е-mail: mykharkovua@gmail.com; ORCID: http://orcid.org/0000-0003-20920456.

Шепеленко Олена Генадіївна - кандидат наук з державного управління, незалежний дослідник; e-mail: mykharkovua@gmail.com; ORCID: http://orcid.org/0000-0001-5927-3298. 